\title{
UPAYA PENYIDIK MELAKUKAN REHABILITASI TERHADAP PENYALAHGUNA NARKOTIKA BAGI DIRI SENDIRI MENURUT UNDANG-UNDANG NARKOTIKA (Studi Pada Satres Narkoba Polres Kepulauan Mentawai )
}

\author{
Defrizal $^{1}$, Otong Rosadi ${ }^{2}$, Wirna Rosmely ${ }^{3}$ \\ Program Studi Pascasarjana Ilmu Hukum \\ Universitas Ekasakti Padang
}

\begin{abstract}
Investigators have an important role to the settlement of cases of narcotics abuse for themselves. In dealing with narcotics abusers for themselves, investigators should be oriented to action sanctions in the form of rehabilitation. This is very necessary in order to operationalize Article 54 of Law Number 35 Year 2009 on Narcotics, where the narcotics abusers for themselves are obliged to undergo medical rehabilitation and social rehabilitation. Based on the results of the study, as well as the discussion and analysis, obtained the conclusion as an answer to the formulation of the problem, as follows: first, the investigator's efforts to the rehabilitation of narcotics narcotics for themselves according to the Narcotics law on Satres Drugs Mentawai Islands Police done by sending a request for an assessment to BNN West Sumatra Province. The request to conduct an assessment to West Sumatra Provincial BNN for suspected Narcotics abusers for themselves is conducted against the suspect with evidence and limit of usage of at most 5 grams. If the evidence brought by the suspect is more than 1 grams, the Satres Drug Investigator of Mentawai Islands Resort does not send a request for an assessment to BNN West Sumatera Province. Second, obstacles encountered by the investigator against the efforts of the rehabilitation of narcotics narcotics for themselves according to the Narcotics law in the Drug Satres Mentawai Islands Police, in the first instance, has not been formed Integrated Assesmen Tim in Mentawai Islands District. Secondly, the lack of community response in the rehabilitation of narcotics narcotics for themselves, where narcotics abusers for themselves and families of narcotics abusers for themselves, no one reports to Satres Drug investigators Mentawai Islands police.
\end{abstract}

Kata Kunci: Penyidik, Narkotika, Rehabilitasi

\section{PENDAHULUAN}

Pengguna atau pecandu narkotika di satu sisi merupakan pelaku tindak pidana, namun di sisi lain merupakan korban. Pengguna atau pecandu narkotika menurut undang-undang sebagai pelaku tindak pidana narkotika adalah dengan adanya ketentuan
Undang-Undang Narkotika yang mengatur mengenai pidana penjara yang diberikan pada para pelaku penyalahgunaan narkotika. Kemudian di sisi lain dapat dikatakan bahwa menurut UU Narkotika, pecandu narkotika tersebut merupakan korban yang harus direhabilitasi. 
Tindakan rehabilitasi merupakan penanggulangan yang bersifat represif yaitu penanggulangan yang dilakukan setelah terjadinya tindak pidana, dalam hal ini narkotika, yang berupa pembinaan atau pengobatan terhadap para pengguna narkotika. Dengan upaya-upaya pembinaan atau pengobatan tersebut diharapkan nantinya korban penyalahgunaan narkotika dapat kembali normal dan berperilaku baik dalam kehidupan bermasyarakat.

Optimilisasi penggunaan rehabilitasi ini diatur dalam pasal 4 huruf d UU Narkotika yang menyatakan bahwa undang-undang narkotika ini dibuat untuk menjamin pengaturan upaya rehabilitasi medis dan sosial. Tidak hanya itu, lebih jelas lagi dijelaskan pada Pasal 54 UU Narkotika yang menyatakan bahwa pecandu narkotika dan korban penyalahgunaan narkotika wajib menjalani rehabilitasi medis dan sosial. Dengan kata lain tidak ada lagi alasan bagi pecandu dan korban penyalahgunaan narkotika untuk tidak di rehabilitasi.

Namun, pada kenyataannya masih banyak pecandu dan korban penyalahgunaan narkotika yang divonis hukuman penjara daripada rehabilitasi. Padahal dalam Pasal 103 ayat (1) Undang-Undang Nomor 35 Tahun 2009 tentang Narkotika ini juga memungkinkan seorang hakim untuk memutuskan pecandu tersebut untuk direhabilitasi. Dalam Pasal 127 ayat (3) UU Narkotika juga memberikan amanat kepada hakim dalam hal orang tersebut terbukti sebagai korban penyalahgunaan narkotika wajib untuk menjalani rahabilitasi medis dan rehabilitasi sosial.

Bukan hanya Undang-Undang Nomor 35 Tahun 2009 tentang Narkotika saja, namun ada juga beberapa peraturan lainnya yang mengatur mengenai rehabilitasi ini seperti Surat Edaran Mahkamah Agung (SEMA) Nomor 4 Tahun 2010 tentang Penempatan Penyalahguna, Korban Penyalahgunaan Narkotika kedalam Lembaga Medis dan Sosial, kemudian pemerintah juga mengeluarkan Peraturan Pemerintah Nomor 25 Tahun 2011 tentang Pelaksanaan Wajib Lapor Pecandu Narkotika untuk mendapatkan layanan terapi dan rehabilitasi, lalu menteri kesehatan juga mengeluarkan Keputusan Menteri Kesehatan Nomor HK.02.02/MENKES/502/2015 yang menunjuk 434 instansi penerima wajib lapor (IPWL) di 33 provinsi dan beserta aturan yang memperkuat aturan ini, seperti Peraturan Bersama Ketua Mahkamah Agung Republik Indonesia, Menteri Hukum dan Hak Asasi Manusia Republik Indonesia, Menteri Kesehatan Republik Indonesia, Menteri Sosial Republik Indonesia, Jaksa Agung Republik Indonesia, Kepala Kepolisian Republik Indonesia, Kepala Badan Narkotika Nasional Republik Indonesia Nomor: 01/PB/MA/III/2014, Nomor: 03 Tahun 2014, Nomor 11 Tahun 2014, Nomor 03 Tahun 2014, Nomor: PER-005/A/JA/03/2014, 
Nomor: 1 Tahun 2014, Nomor PERBER/01/III/2014/BNN

tentang

Penanganan Pecandu Narkotika dan Korban Penyalahgunaan Narkotika ke dalam Lembaga Rehabilitasi. Dengan demikian pecandu dan penyalahguna narkotika tidak lagi bermuara pada sanksi pidana penjara, melainkan bermuara di tempat rehabilitasi, karena sanksi bagi pecandu dan penyalahguna narkotika disepakati berupa rehabilitasi.

Mengenai prosedur tetap dalam pelaksanaan rehabilitasi terhadap pecandu dan penyalahguna narkotika diatur dalam Peraturan Menteri Kesehatan Republik Indonesia Nomor 80 Tahun 2014 tentang Petunjuk Teknis Pelaksanaan Rehabilitasi Medis bagi Pecandu, Penyalahguna, dan Korban Penyalahgunaan Narkotika yang sedang dalam proses penyidikan, penuntutan dan persidangan atau telah mendapatkan penetapan/ putusan pengadilan. Keseriusan pemerintah dalam hal merehabilitasi pecandu dan korban penyahgunaan narkotika tidak dapat dikatakan main-main, begitu banyaknya peraturan yang dikeluarkan dari semua elemen membuat rehabilitasi ini hadir untuk menjadi pemecah masalah yang ada saat ini.

Berdasarkan uraian diatas, dapat dipahami bahwa sekalipun substansi hukum sudah baik, belum tentu dapat terlaksana dengan baik sesuai dengan fungsinya, karena

\footnotetext{
${ }^{1}$ Otong Rosadi dan Andi Desmon, Studi Politik Hukum: Suatu Optik Ilmu Hukum, Thafa Media, Yogyakarta, 2013, hlm. 5-6.
}

dibutuhkan struktur penegak hukum yang handal dalam menjalankan substansi hukum tersebut, disamping budaya hukum juga harus diperhatikan. ${ }^{1}$ Dalam menangani penyalahguna narkotika, aparat penegak hukum harus berorientasi kepada sanksi tindakan berupa rehabilitasi. Hal ini sangat diperlukan dalam rangka mengoperasionalkan Pasal 54 UU Narkotika dimana pecandu narkotika wajib menjalani rehabilitasi medis dan rehabilitasi sosial.

Berkaitan dengan hal tersebut diharapkan penyalahguna narkotika akan dijerat dengan pasal penyalahguna saja (Pasal 127 UU Narkotika), dan selanjutnya hakim dapat menggunakan Pasal 103 UU Narkotika dalam memutus atau menetapkan untuk memerintahkan pecandu menjalani rehabilitasi. Dengan perkataan lain dapat dikatakan bahwa untuk dapat memfungsikan peran hakim dalam memutus atau menetapkan rehabilitasi perlu dukungan dari aparat penegak hukum yang lain. Peranan hakim menurut pendapat Luhut MP Pangaribuan, dengan sistem yang ada sekarang dapat dikatakan sentral, lebih jauh dapat juga dikatakan "monopolistik" atas seluruh aspekaspek dari pemeriksaan suatu perkara di persidangan. $^{2}$

Diantara aparat penegak hukum yang juga mempunyai peran penting terhadap

\footnotetext{
2 Luhut MP Pangaribuan, Advokat dan Contempt of Court, (Satu Proses di Dewan Kehormatan Profesi), Djambatan, Jakarta, 1986, hlm. 18.
} 
adanya kasus tindak pidana penyalahgunaan narkotika ialah Penyidik, yang dalam hal ini adalah Penyidik POLRI, dimana penyidik diharapkan mampu membantu proses penyelesaian terhadap kasus tindak pidana penyalahguna narkotika. Sehingga untuk proses selanjutnya, upaya yang dilakukan oleh penyidik dapat membantu aparat penegak hukum lainnya dalam penyelesaian kasus penyalahguna narkotika.

Salah satu daerah yang rentan terhadap peredaran narkotika adalah Kabupaten Kepulauan Mentawai. Berbagai macam upaya telah dilakukan secara bersama-sama oleh pemerintah daerah untuk mensosialisasikan bahaya narkotika, tetapi tetap saja ada warga masyarakat yang menyalahgunakan narkotika, yang pada gilirannya secara kelembagaan Kepolisian Resort Kepulauan Mentawai menjadi garda terdepan dalam upaya pemberantasan Tindak pidana penyalahgunaan Narkotika. Baru-baru ini, seorang tersangka tindak pidana narkotika diserahkan oleh Penyidik Satuan Reserse Narkoba Polres Kepulauan Mentawai kepada Badan Narkotika Provinsi Sumatera Barat untuk dilakukan assesment.

Berdasarkan uraian tersebut, maka penulis tertarik untuk meneliti mengenai upaya rehabilitasi bagi penyalahguna narkotika bagi sendiri dan menulisnya dalam

3 Ronny Hanitijo Soemitro, Metodologi Penelitian Hukum dan Jurimetri, Ghalia Indonesia, Jakarta, 1998, hlm. 11-33 bentuk tesis dengan judul "Upaya Penyidik Melakukan Rehabilitasi Terhadap Penyalahguna Narkotika Bagi Diri Sendiri Menurut Undang-Undang Narkotika (Studi Pada Satres Narkoba Polres Kepulauan Mentawai)".

\section{METODE PENELITIAN}

Penelitian ini merupakan penelitian deskriptif analitis, yaitu penelitian yang menggambarkan data secara jelas dan teliti yang kemudian dengan data tersebut dianalisis permasalahan yang ada serta dicari penyelesaiannya berdasarkan peraturan perundang-undangan dan peraturan lainnya yang memiliki relevansi dengan penelitian.

Pendekatan utama yang digunakan dalam penelitian ini adalah pendekatan yuridis normatif. Menurut Ronny Hanitijo Soemitro pendekatan penelitian hukum normatif dilakukan dengan cara penelitian terhadap inventarisasi hukum positif, penelitian terhadap asas-asas hukum, penelitian terhadap sistematika hukum serta penelitian terhadap taraf sinkronisasi peraturan perundangundangan, baik secara vertikal maupun secara horizontal. ${ }^{3}$ Sedangkan sebagai pendukung pendekatan utama digunakan pendekatan yuridis empiris, yaitu suatu penelitian yang mengkonsepkan hukum sebagai gejala empiris yang dapat diamati dalam kehidupan. ${ }^{4}$

\footnotetext{
${ }^{4}$ Bambang Sunggono, Metodologi Penelitian Hukum, Rajawali Pers, Jakarta, 2003, hlm. 27.
} 
yang dilakukan dengan cara mengumpulkan semua data yang diperoleh dari lapangan yang berhubungan erat dengan permasalahan penelitian.

Data yang digunakan dalam penelitian ini terdiri atas data primer (primary data) dan data sekunder (secondary data) yang bersumber dari bahan hukum primer, bahan hukum sekunder dan bahan hukum tersier. ${ }^{5}$ Untuk memperoleh data sekunder, dikumpulkan dengan cara melakukan penelitian kepustakaan (library research). Sedangkan untuk memperoleh data primer, dikumpulkan dengan cara melakukan penelitian lapangan (field research).

Data yang diperoleh dari hasil penelitian dianalisis secara kualitatif, yaitu dengan memberikan komentar-komentar dan tidak menggunakan angka-angka. Analisis kualitatif menurut Lexy J. Moleong, merupakan upaya yang dilakukan dengan jalan bekerja dengan data, mengorganisasikan data, memilah-milahnya menjadi suatu yang dapat dikelola, mensintesiskannya, mancari dan menemukan pola, menemukan apa yang penting dan apa yang dipelajari, dan memutuskan apa yang dapat diceritakan kepada orang lain. ${ }^{6}$

Data yang telah dianalis secara kualitatif, kemudian disajikan dalam bentuk deskriptif analitis, yaitu hanya akan menggambarkan saja dari hasil penelitian

\footnotetext{
5 Soerjono Soekanto, Pengantar Penelitian Hukum, UI Press, Jakarta, 1986, hlm. 51-52
}

secara jelas dan teliti, yang berhubungan dengan pokok permasalahan penelitian, yaitu tentang upaya penyidik melakukan rehabilitasi terhadap penyalahguna narkotika bagi diri sendiri menurut undang-undang Narkotika di Satres Narkoba Polres Kepulauan Mentawai, serta kendala yang ditemui penyidik dalam upaya rehabilitasi terhadap penyalahguna narkotika bagi diri sendiri menurut undang-undang Narkotika di Satres Narkoba Polres Kepulauan Mentawai.

\section{HASIL DAN PEMBAHASAN}

Upaya Penyidik Melakukan Rehabilitasi Terhadap Penyelahguna Narkotika Bagi Diri Sendiri Menurut Undang-Undang Narkotika di Satres Narkoba Polres

\section{Kepulauan Mentawai}

Pada hakikatnya hukum itu mengatur masyarakat secara patut dan bermanfaat dengan menetapkan apa yang diharuskan ataupun yang dibolehkan dan sebaliknya. Hukum dapat mengkualifikasi sesuatu perbuatan sesuai dengan hukum atau mendiskusikannya sebagai melawan hukum. Perbuatan yang sesuai dengan hukum tidak merupakan masalah dan tidak perlu dipersoalkan; yang menjadi masalah ialah perbuatan yang melawan hukum, bahkan yang diperhatikan dan digarap oleh hukum ialah justru perbuatan yang disebut terakhir ini, baik perbuatan melawan hukum yang sungguh-

\footnotetext{
${ }^{6}$ Lexy J. Moleong, Metodologi Penelitian Kualitatif, Remaja Rosdakarya, Bandung, 2005, hlm. 248.
} 
sungguh terjadi (onrecht in actu) maupun perbuatan melawan hukum yang mungkin akan terjadi (onrecht in potentie). Perhatian dan penggarapan perbuatan itulah yang merupakan penegakan hukum. Terhadap perbuatan yang melawan hukum tersedia sanksi. ${ }^{7}$

Sanksi merupakan aktualisasi dari norma hukum yang mempunyai karakteristik sebagai ancamaan atau sebagai sebuah harapan. Sanksi akan dapat memberikan dampak positif atau negatif terhadap lingkungan sosialnya, di samping itu, sanksi ialah merupakan penilaian pribadi seseorang yang ada kaitannya dengan sikap perilaku serta hati nurani yang tidak mendapatkan pengakuan atau dinilai tidak bermanfaat bila ditaati. Pengaruh hukum dan konsep tujuan dapat dikatakann bahwa konsep pengaruh berarti sikap tindak atau perilaku yang dikaitkan dengan suatu kaidah hukum dalam kenyataan, perpengaruh positif atau efektivitasnya yang tergantung pada tujuan atau maksud suatu kaidah hukum. Suatu tujuan hukum tidak selalu identik dinyatakan dalam suatu aturan dan belum tentu menjadi alasan yang sesungguhnya dari pembuat aturan tersebut. ${ }^{8}$

Melihat tata hukum secara skematis, maka dapat dibedakan adanya tiga sistem penegakan hukum, ialah sistem penegakan

7 Sudarto, Kapita Selekta Hukum Pidana, Alumni, Bandung, 1981, hlm. 99. hukum perdata, sistem penegakan hukum pidana dan sistem penegakan hukum administrasi. Berturut-turut sistem sanksi hukum perdata, sistem sanksi hukum pidana dan sistem sanksi hukum administrasi. Ketiga sistem penegakan hukum tersebut masingmasing didukung dan dilaksanakan oleh alat perlengkapan negara atau biasa disebut aparatur penegak hukum, yang mempunyai aturannya sendiri- sendiri pula. ${ }^{9}$

Dalam sistem penegakan hukum pidana, dikenal apa yang disebut dengan sistem peradilan pidana. Salah satu tahap dalam sistem peradilan pidana adalah tahap penyidikan, yaitu serangkaian tindakan penyidik dalam hal dan menurut cara yang diatur dalam undang-undang ini untuk mencari serta mengumpulkan bukti yang dengan bukti itu membuat terang tentang tindak pidana yang terjadi dan guna menemukan tersangkanya.

Berdasarkan ketentuan UU Narkotika, kewenangan penyidikan terhadap penyalahgunaan dan peredaran gelap narkotika dan prekursor narkotika dimiliki oleh Penyidik Polri dan Penyidik BNN. Sedangkan Penyidik PPNS tertentu sebagaimana dimaksud dalam KUHAP berwenang melakukan penyidikan terhadap tindak pidana penyalahgunaan narkotika dan prekursor narkotika. Penyidik PPNS tertentu

\footnotetext{
${ }^{8}$ Muladi dan Barda Nawawi Arief, Teori-Teori dan Kebijakan Pidana, Alumni, Bandung, 2010, hlm. 90.

${ }^{9}$ Sudarto, Op. Cit, hlm. 111.
} 
tersebut dapat berasal dari lingkungan kementerian atau lembaga pemerintah non kementerian yang lingkup tugas dan tanggung jawabnya di bidang narkotika dan prekursor narkotika yaitu Kementerian Kesehatan, Kementerian Keuangan dalam hal ini Direktorat Jenderal Bea dan Cukai,dan Badan Pengawas Obat dan Makanan.

Pemeriksaan yang dilakukan oleh penyidik difokuskan sepanjang hal yang menyangkut persoalan hukum. Titik pangkal pemeriksaan dihadapan penyidik ialah tersangka. Dari dialah diperoleh keterangan mengenai peristiwa pidana yang sedang diperiksa. Akan tetapi, sekalipun tersangka yang menjadi titik tolak pemeriksaan, terhadapnya harus diberlakukan asas akusatur. Tersangka harus ditempatkan pada kedudukan menusia yang memiliki harkat martabat. Dia harus dinilai sebagai subjek, bukan sebagai objek. Yang diperiksa bukan manusia tersangka. Perbuatan tindak pidana yang dilakukannyalah yang menjadi objek pemeriksaan. Pemeriksaan tersebut ditujukan ke arah kesalahan tindak pidana yang dilakukan oleh tersangka. Tersangka harus dianggap tak bersalah, sesuai dengan prinsip hukum "praduga tak bersalah" (presumption of innocent ) sampai diperoleh putusan pengadilan yang telah berkekuatan hukum tetap. $^{10}$

\footnotetext{
${ }^{10}$ M. Yahya Harahap, Pembahasan Permasalahan Dan Penerapan KUHAP: Penyidikan Dan Penuntutan, Sinar Grafika, Jakarta, 2006. hlm. 134.
}

Berdasar hasil penelitian yang penulis lakukan pada Satres Narkoba Polres Kepulauan Mentawai, diperoleh data dan informasi bahwa upaya rahabilitasi yang dilakukan oleh penyidik terhadap tersangka penyalahguna Narkotika bagi diri sendiri adalah dengan mengirim permohonan untuk melakukan assesmen kepada BNN Provinsi Sumatera Barat. ${ }^{11}$

Tindakan Penyidik Satres Narkoba Polres Kepulauan Mentawai mengirim permohonan untuk melakukan assesmen kepada BNN Provinsi Sumatera Barat bagi penyalahguna Narkotika bagi diri sendiri ini berdasarkan pada Undang-Undang Nomor 35 Tahun 2009, Peraturan Pemerintah Nomor 25 Tahun 2011, dan Peraturan Bersama Ketua Mahkamah Agung Republik Indonesia, Menteri Hukum dan Hak Asasi Manusia Republik Indonesia, Menteri Kesehatan Republik Indonesia, Menteri Sosial Republik Indonesia, Jaksa Agung Republik Indonesia, Kepala Kepolisian Republik Indonesia, Kepala Badan Narkotika Nasional Republik Indonesia Nomor: 01/PB/MA/III/2014, Nomor: 03 Tahun 2014, Nomor 11 Tahun 2014, Nomor 03 Tahun 2014, Nomor: PER005/A/JA/03/2014, Nomor: 1 Tahun 2014, Nomor PERBER/01/III/2014/BNN tentang Penanganan Pecandu Narkotika dan Korban Penyalahgunaan Narkotika ke dalam

11 Hasil Wawancara dengan IPTU Pareddy Jontara Nababan, selaku Kepala Satres Narkoba Polres Kepulauan Mentawai. 27/03/18. 
Lembaga Rehabilitasi, serta Surat Telegram

Kepala Kepolisian Negara Republik Indonesia

(Kapolri) Nomor: STR/701/VII/2014, Tanggal 22 Agustus 2014.

Ketentuan tersebut pada prinsipnya menyebutkan bahwa terhadap pecandu dan korban penyalahgunaan narkotika dapat direhabilitasi, yaitu mereka yang merupakan pecandu dan korban yang dalam Peraturan Bersama Pasal 4 Ayat (1) ditegaskan sebagai pecandu dan korban yang ditangkap tetapi tanpa barang bukti, namun dari hasil tes urine, darah, rambut dinyatakan positif menggunakan narkotika dan mereka yang dalam Pasal 4 Ayat (2) disebutkan sebagai pecandu dan korban yang ditangkap dengan barang bukti dalam jumlah tertentu dengan atau tidak memakai narkotika sesuai hasil tes urine, rambut, darah atau DNA, selama perkaranya dalam proses peradilan, dalam jangka waktu terentu dapat ditempatkan di lembaga rehabilitasi, setelah dibuatkan Berita Acara Pemeriksaan Hasil laboratorium dan Berita Acara pemeriksaan oleh Penyidik BNN dan dilengkapai surat hasil asesmen terpadu.

Batasan ketentuan jumlah narkotika yang menjadi barang bukti tersebut juga diatur dalam Pasal 112 Ayat (2) Undang-Undang Nomor 35 Tahun 2009 tentang Narkotika, yang menyebutkan bahwa perbuatan memiliki, menyimpan, menguasai atau menyediakan narkotika Golongan I bukan tanaman, apabila beratnya melebihi 5 gram, ancaman pidana bagi pelaku yaitu pidana penjara seumur hidup atau pidana penjara paling singkat 5 tahun dan denda maksimum 8 milyar ditambah 1/3 (satu per tiga). Namun aturan tersebut ditujukan bagi orang yang menyimpan, memiliki dan menguasai, bukan pecandu atau korban penyalahguna. Dari aturan tersebut, bisa dilihat betapa berat ancaman pidana bagi orang yang melakukan tindak pidana narkotika dengan membawa barang bukti melebihi 5 gram.

Tindakan yang dilakukan oleh penyidik Satres narkoba Polres Kepulauan Mentawai terhadap penyalahguna narkotika bagi diri sendiri dengan bukti pemakaian lebih dari 1 gram sehari, dengan tidak mengirimkan permohonan untuk melakukan assesmen kepada BNN Provinsi Sumatera Barat, sehingga tidak dapat dilakukan upaya rehabilitasi, sebagaimana yang ditentukan dalam Pasal 4 ayat (4) Peraturan Bersama, menurut penulis dapat dikatakan sebagai suatu tindakan yang hati-hati.

Dalam Surat Telegram Kapolri Nomor 701 Tahun 2014, ditentukan bahwa permohonan rehabilitasi bagi pecandu dan korban penyalahgunaan narkotika yang berstatus tersangka harus diajukan secara tertulis oleh tersangka atau pihak keluarga atau penasehat hukum tersangka kepada penyidik. Menurut keterangan Kepala Satres Narkoba Polres Kepulauan Mentawai, upaya penyidik Satres Narkoba Polres Kepulauan Mentawai yang mengirimkan permohonan untuk melakukan assesmen kepada BNN 
Provinsi Sumatera Barat terhadap penyalahguna narkotika bagi diri sendiri tersebut berdasarkan inisiatif dari penyidik, sementara permohonan dari tersangka atau pihak keluarga atau penasehat hukum tersangka kepada penyidik belum pernah ada. $^{12}$

Pada prinsipnya perbuatan menggunakan dan menyalahgunakan narkotika bagi diri sendiri merupakan satu perbuatan pidana, sehingga terhadap pelaku sudah selayaknya dilakukan proses hukum sebagaimana layaknya proses hukum terhadap perkara pidana lainnya. Namun untuk saat ini penegakan hukum terhadap pecandu dan penyalahguna narkotika bagi diri sendiri sudah tidak selalu menggunakan sarana penal, melainkan menggunakan sarana non penal, misalnya penyantunan dan pendidikan sosial dalam rangka mengembangkan tanggung jawab sosial warga masyarakat. ${ }^{13}$

Secara umum dapat dibedakan bahwa upaya penanggulangan tindak pidana, sarana penal lebih menitikberatkan pada sifat represif (penindasan/ pemberantasan/ penumpasan) sesudah tindak pidana tersebut terjadi. Sedangkan sarana non penal lebih menitikberatkan pada sifat preventif (pencegahan/penangkalan/ pengendalian) sebelum tindak pidana dimaksud terjadi. ${ }^{14}$

12 Hasil Wawancara dengan IPTU Pareddy Jontara Nababan, selaku Kepala Satres Narkoba Polres Kepulauan Mentawai. 27/03/18.

13 Abintoro Prakoso, Kriminologi dan Hukum Pidana, Laksbang Pressindo, Yogyakarta, 2017, hlm. 178.
Karena adanya keharusan rehabilitasi bagi para pecandu dan penyalahguna narkotika bagi diri sendiri yang melaporkan diri pada instansi penerima wajib lapor, sebagaimana yang ditentukan dalam Pasal 54 Undangundang Nomor 35 Tahun 2009 tentang Narkotika.

Pidana dan tindakan (maatregel) termasuk sanksi dalam hukum pidana. KUHP sendiri tidak menyebut istilah maatregel (tindakan) tetapi menyebutkan sebagai hal-hal yang menghapuskan, mengurangi dan memberatkan pidana. Dalam hal menghapuskan pidana, sanksi tindakan ini dimaksudkan untuk mengamankan masyarakat dan memperbaiki pembuat, seperti pendidikan paksa, pengobatan paksa, memasukan ke dalam rumah sakit jiwa, dan menyerahkan kepada orang tua. ${ }^{15}$

Sanksi pidana menurut Muladi dan Barda Nawawi Arief, lebih bersifat pembalasan terhadap pelaku tindak pidana, sedangkan sanksi tindakan lebih bersifat antisipatif dan juga perbaikan terhadap pelaku perbuatan tersebut. Fokus sanksi pidana tertuju pada perbuatan salah seorang lewat pengenaan penderitaan (agar yang bersangkutan menjadi jera), sedangkan fokus sanksi tindakan terarah pada upaya memberi pertolongan agar pelaku tindak pidana

\footnotetext{
14 Sudarto, Op. Cit, hlm. 118.

15 Andi Hamzah, Asas-Asas Hukum Pidana, Rineka Cipta, Jakarta, 2008, hlm. 218.
} 
berubah. Dengan perkataan lain, sanksi tindakan ini berhubungan dengan tujuan pemidanaan yang bersifat relatif. ${ }^{16}$

Sanksi pidana lebih menekankan unsur pembalasan/pengimbalan yang merupakan penderitaan yang sengaja dibebankan kepada seorang pelanggar. Sedangkan sanksi tindakan bersumber dari ide dasar perlindungan masyarakat dan pembinaan atau perawatan si pembuat. ${ }^{17}$ Sanksi tindakan tujuannya lebih bersifat mendidik, dari sudut teori-teori pemidanaan maka sanksi tindakan merupakan sanksi yang tidak membalas. Ditujukan pada prevensi khusus, yakni melindungi masyarakat dari ancaman yang dapat merugikan kepentingan masyarakat itu sendiri. ${ }^{18}$

Secara singkat, Andi Hamzah mengatakan bahwa sanksi pidana berorientasi pada ide pengenaan sanksi terhadap pelaku suatu perbuatan, sementara sanksi tindakan berorientasi pada ide perlindungan masyarakat. Aspek maatregel (tindakan) terhadap pelaku penyalah guna narkotika adalah dengan cara mengamankan masyarakat dan memperbaiki pembuat (penyalahguna narkotika), dengan cara pengobatan paksa. ${ }^{19}$ Didalam ketentuan UU Narkotika beserta berbagai macam aturan pelaksananya, pengobatan dan atau perawatan tersebut adalah dalam bentuk rehabilitasi medis dan rehabilitasi sosial.

\footnotetext{
${ }^{16}$ Muladi dan Barda Nawawi Arief, Op.Cit, hlm. 10.

${ }^{17}$ Ibid.
}

Rehabilitasi medis pecandu dan penyalahguna narkotika dilakukan agar seorang pecandu dapat terbebas dari ketergantungan zat narkotika tersebut, sedangkan rehabilitasi sosial adalah untuk mengembalikan kemampuan fisik dan dan mental seorang pecandu agar dapat kembali kepada kehidupan sosialnya.

Pengobatan dan perawatan terhadap penyalahguna narkotika bagi diri sendiri dilakukan melalui fasilitas rehabilitasi. Rehabilitasi bagi penyalahguna narkotika bagi diri sendiri dilakukan dengan maksud untuk memulihkan dan mengembangkan kemampuan fisik, mental dan sosial penderita yang bersangkutan.

Korban kejahatan yang bersifat adiksi dalam hal ini adalah pecandu narkotika (termasuk penyalahguna narkotika bagi diri sendiri) membutuhkan perlakuan khusus, agar mereka mendapatkan perawatan dan perlindungan sehingga dapat kembali menjadi warga negara yang mampu berperan dalam kehidupan berbangsa dan bernegara.

Terjadinya pergeseran bentuk pemidanaan dari hukuman badan menjadi hukuman tindakan merupakan proses depenalisasi. Depenalisasi ini terjadi karena adanya perkembangan atau pergeseran nilai hukum dalam kehidupan masyarakat yang mempengaruhi perkembangan nilai hukum pada norma hukum pidana. Perbuatan tersebut

\footnotetext{
${ }^{18}$ Andi Hamzah, Op, Cit, hlm. 217

${ }^{19}$ Ibid, hlm. 193.
} 
tetap merupakan perbuatan yang tercela namun tidak pantas dikenai sanksi pidana yang berat, lebih tepat dikenai sanksi pidana ringan atau tindakan. ${ }^{20}$

$$
\text { Adapun alasan menentukan }
$$

depenalisasi terhadap pengguna dan korban narkotika,karena mereka dianggap sebagai orang yang sakit sehingga perlu mendapatkan perawatan dengan memberikan terapi maupun obat agar sembuh. Terhadap korban penyalahguna narkotika, sesungguhnya mereka tidak menyadari dengan apa yang telah mereka perbuat disebabkan mereka melakukan perbuatan tersebut karena bujuk rayu orang lain sehingga perlu diselamatkan dengan direhabilitasi, supaya tidak terjerumus dalam keparahan dampak narkotika. ${ }^{21}$

Meskipun penyalahguna narkotika bagi diri sendiri memiliki kualifikasi sebagai pelaku tindak pidana narkotika, namun didalam keadaan tertentu pecandu narkotika dapat berkedudukan lebih kearah korban. Iswanto menyatakan bahwa korban merupakan akibat perbuatan disengaja atau kelalaian, kemauan suka rela, atau dipaksa atau ditipu, bencana alam, dan semuanya benar-benar berisi sifat penderitaan jiwa, raga, harta dan morel serta sifat ketidakadilan". 22 penyalahguna narkotika bagi diri sendiri dapat dikatakan sebagai korban dari tindak pidana

20 Mudzakir, Dekriminaliasi Pecandu Narkotika, Makalah yang Disampaikan pada Focus Group Discussion yang diselenggarakan oleh Badan Narkotika Nasional bekerjasama dengan Fakultas Hukum Universitas Gadjah Mada tanggal 10 Oktober 2014. penyalahgunaan narkotika yang dilakuknnya sendiri, dengan demikian penyalah guna mempunyai hak-haknya sebagai korban dari kejahatan.

Stephen Schafer sebagaimana dikutip oleh Rena Yulia mengatakan bahwa terdapat 7 tujuh tipologi korban apabila ditinjau dari perspektif tanggung jawab korban itu sendiri, yaitu sebagai berikut:

a. Unrelated victims (korban yang tidak terkait), yaitu korban yang tidak ada hubungannya sama sekali dengan pelaku dan menjadi korban karena memang potensial.

b. Provocative victims (korban provokatif), yaitu seseorang atau korban yang disebabkan peranan korban untuk memicu terjadinya kejahatan.

c. Participating victims (korban berpartisipasi), yaitu seseorang tidak berbuat, akan tetapi dengan sikapnya justru mendorong dirinya menjadi korban.

d. Biologically weak victims (korban biologis lemah), yaitu mereka yang secara fisik memiliki kelemahan yang menyebabkan ia menjadi korban.

e. Socially weak victims (korban yang secara sosial lemah), yaitu mereka yang memiliki kedudukan sosial yang lemah menyebabkan ia menjadi korban.

${ }^{21}$ Ibid.

${ }^{22}$ Iswanto, Viktimologi, Fakultas Hukum Universitas Jenderal Soedirman, Purwokerto, 2009, hlm. 8. 
f. Self victimizing victims (korban yang juga sebagai tumbal), yaitu mereka yang menjadi korban karena kejahatan yang dilakukannya sendiri.

g. Political victims (korban politik), yaitu korban karena lawan politiknya sosiologis, korban tidak dapat dipertanggungjawabkan kecuali adanya perubahan konstelasi politik. ${ }^{23}$

Pihak yang mengalami penderitaan dan kerugian atau di sebut sebagai korban tentu mempunyai hak-hak yang dapat diperoleh sebagai seorang korban. Hak-hak korban menurut van boven sebagaimana dikutip oleh Rena Yulia, adalah hak untuk tahu, hak atas keadilan dan hak katas reparasi (pemulihan), yaitu hak yang menunjuk kepada semua tipe pemulihan, baik material maupun non material.

\section{Kendala yang Ditemui Dalam Upaya Penyidik Melakukan Rehabilitasi Terhadap Penyelahguna Narkotika Bagi Diri Sendiri Menurut Undang-Undang Narkotika di Satres Narkoba Polres \\ Kepulauan Mentawai}

Masalah penegakan hukum merupakan masalah yang sangat penting dalam rangka menciptakan tata tertib, ketentraman, dan keamanan dalam kehidupan suatu masyarakat. Hukum pada dasarnya berfungsi untuk memberikan perlindungan terhadap

23 Rena Yulia, Viktimologi, Graha ilmu, Yogyakarta, 2010, hlm. 53-54. kepentingan manusia, sehingga hukum harus dijunjung tinggi dalam rangka menciptakan tatanan masyarakat yang tertib dan damai. Demikian halnya bagi penyalahgunaan narkotika, hukum juga wajib untuk diberikan dan ditegakkan sesuai dengan ketentuan yang berlaku di Indonesia sehingga dapat menegakkan keadilan bagi tegaknya supremasi hukum.

Penyalahgunaan narkotika bagi diri sendiri secara tidak sah selain merupakan kejahatan juga berakibat buruk bagi kesehatan bagi para penyalahguna narkotika, dimana para penyalahguna narkotika menjadikan hidupnya diliputi ketergantungan kepada obat-obatan terlarang, walaupun harganya mahal dan tidak mudah dicari. Pengobatannya tidak sederhana, diperlukan waktu yang tidak sedikit, serta diperlukan juga perhatian secara khusus.

Berdasarkan dampak yang ditimbulkan dari penyalahgunaan narkotika yang salah, maka keikutsertaan pemerintah dan masyarakat untuk memerangi penyalahgunaan narkotika sangat bermanfaat untuk mengurangi, memberantas, mempersempit ruang gerak peredaran gelap narkotika serta pelaksanaan sebagai upaya penanggulangan tindak pidana narkotika.

Secara umum dapat dipahami bahwa kebijakan dalam pencegahan penyalahgunaan dan peredaran gelap narkotika, disamping 
dengan menggunakan teori-teori represif dan preventif, tidak kalah pentingnya ialah dengan menggunakan strategi pengobatan dan rehabilitasi. Hal ini mengandung pemikiran bahwa para korban penyalahguna narkotika, tidak hanya sekedar dianggap sebagai pelaku tindak pidana, akan tetapi juga dianggap sebagai korban kejahatan yang memerlukan penyembuhan dan rehabilitasi. ${ }^{24}$

Berbagai kebijakan lahir dari pemerintah untuk mencegah, menanggulangi, mengobati dan pemberantasan narkotika itu sendiri, begitupun berbagai regulasi peraturan perundang-undangan yang telah dilahirkan, diantaranya pengobatan terhadap pecandu dan penyalahguna narkotika. Pecandu Narkotika dan korban penyalahgunaan Narkotika wajib menjalani rehabilitasi medis dan rehabilitasi sosial, yaitu suatu proses kegiatan pemulihan secara terpadu, baik fisik, mental maupun sosial, agar bekas pecandu Narkotika dapat kembali melaksanakan fungsi sosial dalam kehidupan masyarakat.

Dalam upaya rehabilitasi terhadap penyalahguna narkotika bagi diri sendiri tentunya tidak terlepas dari kendala-kendala yang dialami. Kendala tersebut dapat bersumber dari aturan hukum yang menjadi acuan bagi penegak hukum dan masyarakat, dari penegak hukum sendiri, dan dapat pula bersumber dari masyarakat itu sendiri.

${ }^{24}$ Siswanto Sunarno, Politik Hukum Dalam UndangUndang Narkotika (UU RI Nomor 35 Tahun 2009), Rineka Cipta, Jakarta, 2012, hlm. 29.
Berdasarkan keterangan yang diberikan oleh Kepala Satuan Reserse Narkoba Polres Kepulauan Mentawai, diperoleh informasi bahwa dalam upaya rehabilitasi terhadap penyalahguna narkotika masih ditemui beberapa kendala sehingga upaya rehabilitasi yang dilakukan oleh penyidik terhadap penyalahguna narkotika tidak dapat terlaksana secara maksimal. Adapaun yang menjadi kendala bagi penyidik dalam upaya rehabilitasi penyalahguna Narkotika bagi diri sendiri pada Satuan Reserse Narkoba Polres Kepulauan Mentawai adalah belum terbentuknya tim assesment terpadu pada tingkat Kabupaten Kepulauan Mentawai. ${ }^{25}$

Berdasarkan ketentuan Pasal 13 Ayat (3) Peraturan Pemerintah Nomor 25 Tahun 2011 tentang Pelaksanaan Wajib lapor bagi Pecandu Narkotika, disebutkan bahwa pecandu yang sedang menjalani proses peradilan dapat ditempatkan dalam lembaga rehabilitasi medis dan/atau rehabilitasi sosial. Lebih lanjut dalam Ayat (4) ditentukan bahwapenentuan rehabilitasi pecandu menjadi kewenangan penyidik, penuntut umum dan hakim setelah mendapat rekomendasi dari tim dokter.

Berdasar ketentuan dalam peraturan pemerintah tersebut diatas, dapat disimpulkan bahwa yang dapat direhabilitasi medis maupun sosial tidak hanya terbatas bagi

25 Hasil Wawancara dengan IPTU Pareddy Jontara Nababan, selaku Kepala Satres Narkoba Polres Kepulauan Mentawai. 27/03/18. 
pecandu yang melaporkan diri, namun pecandu, korban penyalahguna yang perkaranya diperiksa oleh penegak hukum, yaitu mereka yang ditangkap, tertangkap tangan, dapat direhabilitasi oleh petugas yang sedang menangani perkaranya.

Penegakan hukum terhadap persoalan narkotika terutama terhadap para pecandu maupun korban penyalahguna yang belum sesuai dengan amanahnya, menimbulkan permasalahan narkotika semakin kompleks sehingga jumlah korban penyalahguna, pecandu dan pengedar dari tahun ke tahun semakin bertambah banyak.

Melihat kenyataan tersebut BNN berinisiatif untuk lebih memberi perhatian terutama pada pecandu, korban penyalahgunaan narkotika dengan menggiatkan pemberian rehabilitasi. Untuk itu BNN melakukan kerjasama dengan beberapa instansi pemerintah yang dapat dilibatkan dalam rehabilitasi. Bentuk kerjasama tersebut diwujudkan dalam bentuk Peraturan Bersama.

Dengan ditetapkan Peraturan Bersama antara 7 (tujuh) Lembaga Negara Republik Indonesia pada tanggal 11 Maret 2014 tentang Penanganan Pecandu Narkotika dan Korban Penyalahgunaan Narkotika ke dalam Lembaga Rehabilitasi, proses penyidikan terhadap pecandu maupun penyalahguna narkotika mengalami perubahan. Bagi pecandu dan penyalahguna narkotika yang ditangkap maupun tertangkap tangan, maka akan dilakukan asesmen oleh tim asesmen terpadu yang terdiri dari unsur: a. Tim dokter yang terdiri dari dokter dan psikolog; b. Tim hukum yang terdiri dari unsur Polri, BNN, Kejaksaan dan Kemenkumham.

Tim Asesmen Terpadu terdiri dari Tim Dokter, yang mana Tim Dokter disini meliputi Dokter dan Psikolog, dokter disini juga merupakan tenaga kesehatan yang berwenang memberikan pelayanan kesehatan kepada masyarakat, serta Tim Hukum, yang mana Tim Hukum disini terdiri dari unsur POLRI, Badan Narkotika Nasional, Kejaksaan, dan Kemenkumham. Kedua tim inilah yang bekerja sama dalam hal proses asesmen terhadap pemohon.

Tim Asesmen Terpadu merupakan tim dalam hal penanganan proses asesmen sebagai tolak ukur Pecandu Narkotika dan Korban Penyalahgunaan Narkotika akan Narkotika itu sendiri, serta lamanya masa rehabilitasi terhadap pemohon. Ada beberapa tugas dan wewenang yang dimiliki Tim Asesmen itu sendiri. Tugas dari Tim Asesmen itu sendiri adalah menganalisis terhadap seseorang yang ditangkap dan/atau tertangkap tangan, jika Pecandu tersebut tertangkap tangan, dalam kaitannya dengan peredaran gelap Narkotika dan penyalahgunaan Narkotika, dan asesmen dan analisis medis, psikososial, serta merekomendasi rencana terapi dan rehabilitasi seseorang tersebut yang sebagai pemohon.

Adapun tugas dari tim asesmen terpadu yaitu untuk menghentikan peredaran gelap 
narkotika dan penyalahgunaan narkotika serta melakukan asesmen dan analisa medis, psikososial dan merekomendasi rencana terapi dan rehabilitasi pecandu dan penyalahguna narkotika.

\section{PENUTUP}

Upaya penyidik melakukan rehabilitasi terhadap penyalahguna narkotika bagi diri sendiri menurut undang-undang Narkotika di Satres Narkoba Polres Kepulauan Mentawai dilakukan dengan cara mengirimkan permohonan untuk melakukan assesmen kepada BNN Provinsi Sumatera Barat. Permohonan untuk melakukan assesmen kepada BNN Provinsi Sumatera Barat bagi tersangka penyalahguna Narkotika bagi diri sendiri dilakukan terhadap tersangka dengan barang bukti dan batasan pemakaian paling banyak 1 gram. Apabila barang bukti yang dibawa tersangka lebih dari 1 gram, penyidik Satres Narkoba Polres Kepulauan Mentawai tidak mengirimkan permohonan untuk melakukan assesmen kepada BNN Provinsi Sumatera Barat.

Kendala yang ditemui dalam upaya penyidik melakukan rehabilitasi terhadap penyalahguna narkotika bagi diri sendiri menurut undang-undang Narkotika di Satres Narkoba Polres Kepulauan Mentawai, berupa pertama, belum terbentuknya Tim Assesmen Terpadau di Kabupaten Kepulauan Mentawai. Kedua, kurangnya respon masyarakat dalam upaya rehabilitasi penyelahguna narkotika bagi diri sendiri, dimana para penyalahguna narkotika bagi diri sendiri dan keluarga penyalahguna narkotika bagi diri sendiri, tidak ada yang melapor pada penyidik Satres Narkoba Polres Kepulauan Mentawai.

\section{DAFTAR PUSTAKA}

\section{Buku-Buku}

Abintoro Prakoso, Kriminologi dan Hukum Pidana, Laksbang Pressindo, Yogyakarta, 2017.

Adhi Wibowo, Hukum Acara Pidana Dalam Teori dan Praktek, Hayfa Press, Padang, 2012.

Adi Sujatno, Pencerahan Dibalik Penjara: Dari Sangkar Menuju Sanggar Untuk Menjadi Manusia Mandiri, Teraju, Jakarta, 2008.

Andi Hamzah, Asas-Asas Hukum Pidana, Rineka Cipta, Jakarta, 2008.

Badan Narkotika Nasional, Pedoman Pencegahan Penyalahgunaan Narkoba Bagi Pemuda, Badan Narkotika Nasional Republik Indonesia, Jakarta, 2011.

Bambang Sunggono, Metodologi Penelitian Hukum, Rajawali Pers, Jakarta, 2003.

Hari Sasangka, Narkotika dan Psikotropika Dalam Hukum Pidana, Mandar Maju, Bandung, 2003.

Iswanto, Viktimologi, Fakultas Hukum Universitas Jenderal Soedirman, Purwokerto, 2009.

Lexy J. Moleong, Metodologi Penelitian Kualitatif, Remaja Rosdakarya, Bandung, 2005.

Luhut MP Pangaribuan, Advokat dan Contempt of Court, (Satu Proses di Dewan Kehormatan Profesi ), Djambatan, Jakarta, 1986.

M. Yahya Harahap, Pembahasan Permasalahan Dan Penerapan 
KUHAP: Penyidikan Dan Penuntutan, Sinar Grafika, Jakarta, 2006.

Muladi dan Barda Nawawi Arief, Teori-Teori dan Kebijakan Pidana, Alumni, Bandung, 2010.

Otong Rosadi dan Andi Desmon, Studi Politik Hukum: Suatu Optik Ilmu Hukum, Thafa Media, Yogyakarta, 2013.

Rena Yulia, Viktimologi, Graha ilmu, Yogyakarta, 2010.

Ronny Hanitijo Soemitro, Metodologi Penelitian Hukum dan Jurimetri, Ghalia Indonesia, Jakarta, 1998.

Siswanto Sunarno, Politik Hukum Dalam Undang-Undang Narkotika (UU RI Nomor 35 Tahun 2009), Rineka Cipta, Jakarta, 2012.

Soerjono Soekanto, Pengantar Penelitian Hukum, UI Press, Jakarta, 1986.

Sudarto, Kapita Selekta Hukum Pidana, Alumni, Bandung, 1981.

\section{Peraturan Perundang-Undangan}

Undang-Undang Dasar Negara Republik Indonesia Tahun 1945.

Undang-undang Nomor 1 Tahun 1946 tentang Peraturan Hukum Pidana (KUHP).

Undang-undang Nomor 8 Tahun 1981 Tentang Hukum Acara Pidana (KUHAP).

Undang-undang Nomor 2 Tahun 2002 tentang Kepolisian Negara Republik Indonesia.

Undang-undang Nomor 35 Tahun 2009 tentang Narkotika.

Peraturan Pemerintah Nomor 27 Tahun 1983 tentang Pelaksanaan Undang-undang Nomor 8 Tahun 1981 Tentang Hukum Acara Pidana sebagaimana yang telah diubah dengan Peraturan Pemerintah Nomor 58 Tahun 2010 tentang Perubahan Atas Peraturan Pemerintah Nomor 27 Tahun 1983 tentang
Pelaksanaan Undang-undang Nomor 8 Tahun 1981 Tentang Hukum Acara Pidana.

Peraturan Pemerintah Nomor 25 Tahun 2011 Tentang Pelaksanaan Wajib Lapor Pecandu Narkotika.

Peraturan Pemerintah Nomor 40 Tahun 2013 tentang Pelaksanaan Undang-undang Nomor 35 Tahun 2009 tentang Narkotika.

Peraturan Bersama Ketua Mahkamah Agung Republik Indonesia, Menteri Hukum dan Hak Asasi Manusia Republik Indonesia, Menteri Kesehatan Republik Indonesia, Menteri Sosial Republik Indonesia, Jaksa Agung Republik Indonesia, Kepala Kepolisian Republik Indonesia, Kepala Badan Narkotika Nasional Republik Indonesia Nomor: 01/PB/MA/III/2014, Nomor: 03 Tahun 2014, Nomor 11 Tahun 2014, Nomor 03 Tahun 2014, Nomor: PER005/A/JA/03/2014, Nomor: 1 Tahun 2014, Nomor PERBER/01/III/2014/BNN tentang Penanganan Pecandu Narkotika dan Korban Penyalahgunaan Narkotika ke dalam Lembaga Rehabilitasi;

Keputusan Menteri Kesehatan Nomor 1305 Tahun 2011 tentang Penetapan Institusi Penerima Wajib Lapor.

Keputusan Menteri Sosial Nomor 2171 Tahun 2011 tentang Tata Cara Wajib Lapor Pecandu Narkotika. 